\title{
Preliminary Phytochemical Screening and Biological Activities of Bulbine abyssinica Used in the Folk Medicine in the Eastern Cape Province, South Africa
}

\author{
Cromwell Mwiti Kibiti and Anthony Jide Afolayan \\ Medicinal Plants and Economic Development (MPED) Research Centre, Department of Botany, University of Fort Hare, \\ Alice 5700, South Africa
}

Correspondence should be addressed to Anthony Jide Afolayan; aafolayan@ufh.ac.za

Received 2 July 2015; Revised 2 September 2015; Accepted 20 September 2015

Academic Editor: Nunziatina De Tommasi

Copyright (C) 2015 C. M. Kibiti and A. J. Afolayan. This is an open access article distributed under the Creative Commons Attribution License, which permits unrestricted use, distribution, and reproduction in any medium, provided the original work is properly cited.

\begin{abstract}
Bulbine abyssinica A. Rich. is used in traditional medicine to treat rheumatism, dysentery, bilharzia, cracked lips, back pain, infertility, diabetes mellitus, and gastrointestinal, vaginal, and bladder infections. Therefore, preliminary phytochemical screening, antioxidant, anti-inflammatory, and antibacterial properties of the whole plant (acetone and aqueous extracts) were determined using standard procedures. The in vitro antioxidant model assays revealed that the plant possesses free radical scavenging potential varying with free radical species. The species showed significant protein denaturation inhibitory activity with good protection against erythrocyte membrane lysis indicating anti-inflammatory potential. The results also showed that the species was active against the growth of all the selected eight diabetic status opportunistic bacteria except one. Moreover, the species is characterized by appreciable amounts of total phenols, flavonoids, flavanols, proanthocyanidins, and alkaloids. Traces amounts of saponins and tannins were also observed. Amongst the identified phytochemicals present, empirical searches identified them being antioxidant, anti-inflammatory, and antimicrobial agents. The identification of these phytochemical constituents with their known pharmacological properties indicates that this plant is a good source of the free radical scavenging, anti-inflammatory, and antimicrobial agents. These findings also account for the multipharmacological use of B. abyssinica in fork medicine.
\end{abstract}

\section{Introduction}

Many diseases are caused by oxidative stress that results from imbalance between the formation and neutralization of free radicals [1]. Oxidative stress initiated by reactive oxygen species (ROS) such as superoxide anions, hydrogen peroxide, hydroxyl, nitric oxide, and peroxynitrite damages cellular macromolecules such as DNA, proteins, and lipids [2]. Among the effects, lipid peroxidation initiates inflammation processes. Therefore, inflammation is intertwined to oxidative stress [3].

The mechanism of inflammation is also ascribed with the release of ROS, stimulating the release of inflammation factors such as cytokines which activates release of neutrophils and macrophages. During inflammatory pathogenesis, there is an excessive activation of phagocytes, production of free radicals which increase vascular permeability, protein denaturation, and membrane alteration [4]. Thus, free radicals are vital mediators that provoke/sustain inflammatory processes and consequently, their neutralization by antioxidants can attenuate inflammation [4]. This cellular oxidative damage may result in diseases including diabetes mellitus, atherosclerosis, myocardial infarction, and neurodegenerative diseases [5]. Microbial invasion during diabetes mellitus status and in other disease conditions is attributed to the host having susceptible damaged cells due to inflammation [5].

Diabetic patients are prone to develop bacterial and fungal infections [6]. The common microbes implicated in these 
infections include Streptococcus pneumonia, Escherichia coli, Staphylococcus aureus, Staphylococcus epidermidis, Pseudomonas aeruginosa, and Candida albicans [7]. Shigella flexneri, Proteus vulgaris, Klebsiella pneumoniae, and Enterococcus faecalis lead to diabetes foot ulcer [8-11]. The bacteria associated with gastrointestinal and urinary tract infections include Klebsiella pneumoniae, Streptococcus pyogenes, and Serratia marcescens [12-14]. Therefore, plant remedies are known to attenuate these infections through acting as antimicrobial agents or by reducing/neutralizing ROS generated during pathophysiology of these diseases and/or by reducing inflammation status [15].

Human cells have an array of protective mechanisms in prevention of the production of free radicals and attenuation of oxidative damage [16]. These mechanisms include release of enzymatic and nonenzymatic antioxidants such as superoxide dismutase, catalase, glutathione reductase, glutathione peroxidase, ascorbic acid, and tocopherol [16]. The protective roles of these enzymes may be disrupted as a result of various pathological processes, thereby causing damage to the cells. Therefore, the cells also offer protection against inflammation via inhibiting protein denaturation agents and protection against membrane lysis [17]. Synthetic antioxidants (such as butylated hydroxyanisole and butylated hydroxytoluene) and nonsteroidal inflammatory drugs (such as diclofenac sodium and aspirin) are commercially available and currently used [17]. However, these drugs have side effects; hence this has led to seeking alternative medicine from plant remedies [17].

Medicinal plants play important roles as source of antioxidant, inflammatory, and antibacterial agents. These bioactivities are mainly due to the presence of phenolic compounds [18]. Among these plants is the Bulbine abyssinica A. Rich. (Asphodelaceae). Bulbine abyssinica is a succulent perennial herb with rhizomatous base which grows in small clusters. The plant is a water-wise plant with both flowers and fruits having yellow and black colors. The roots are many, slender or swollen. B. abyssinica occurs from the Eastern Cape, through KwaZulu-Natal, Swaziland, and Lesotho, and further north to Ethiopia [19].

B. abyssinica is used in South Africa fork medicine to treat rheumatism, dysentery, bilharzia, cracked lips, infertility, back pain, and gastrointestinal, vaginal, and bladder infections [20]. A decoction prepared from the whole plant is used in the management of diabetes mellitus [21].

Studies have shown that the stems and roots of Bulbine species contain anthraquinones that possess antibacterial properties [22]. Anthraquinones, phenylanthraquinones, and isofuranonaphthoquinones have also been isolated from the roots, leaves, and fruits of this plant [22]. The phenylanthraquinone isolated from the roots has in vitro antiplasmodial activity and no cytotoxic effects on mammalian cell lines [22].

Though some of the B. abyssinica's chemical compounds and bioactivities from some plant's parts have been elucidated, the phytochemical constituents, antioxidant, antiinflammatory, and antibacterial properties remain obscure. Therefore, the aim of this study was to quantify the presence of some phytochemical constituents and evaluate these pharmacological activities of acetone and aqueous whole plant extracts of B. abyssinica used in the treatment of diabetes mellitus and associated infections using standard procedures and relate our findings to their folklore uses.

\section{Materials and Methods}

2.1. Plant Collection and Preparation. The whole plant of B. abyssinica including the leaves, flowers, stems, and roots was collected from lower Ncera location in Nkonkobe Municipality of the Eastern Cape Province, South Africa. The voucher specimen (KibMed 2014/01) was deposited in Giffen's herbarium, University of Fort Hare, South Africa, for authentication.

2.2. Extraction Methods. The plant samples were air-dried, ground to homogeneous powder, and extracted using acetone and water. For acetone extraction, the solvent and ground samples were mixed on a shaker for $48 \mathrm{~h}$, while aqueous extraction was done by boiling the samples in distilled water for $30 \mathrm{~min}$ and let to cool. These extracts were then filtered. The filtrate obtained with water extraction was frozen at $-40^{\circ} \mathrm{C}$ and freeze-dried for $48 \mathrm{~h}$ using a freeze dryer (Vir Tis benchtop K, Vir Tis Co., Gardiner, NY). The acetone extracts were concentrated to dryness under reduced pressure at $57^{\circ} \mathrm{C}$ using a rotary evaporator (Strike 202 Steroglass, Italy). The resulting extracts were reconstituted with their respective solvents to give the desired concentrations used in the study.

2.3. Chemicals and Reagents Used. All the chemicals used were of analytical grade and were purchased from Merck and Sigma-Aldrich, Gauteng, South Africa.

\subsection{Phytochemical Analysis}

2.4.1. Determination of Total Phenols. The total phenolic content in the extracts was determined by the modified FolinCiocalteu method [23]. An aliquot of $0.5 \mathrm{~mL}$ of each plant extract $(1 \mathrm{mg} / \mathrm{mL})$ was mixed with $5 \mathrm{~mL}$ of Folin-Ciocalteu reagent which was previously diluted with distilled water $(1: 10 \mathrm{v} / \mathrm{v})$ and $4 \mathrm{~mL}(75 \mathrm{~g} / \mathrm{L})$ of sodium carbonate. The mixtures were vortexed for $15 \mathrm{sec}$ and allowed to stand for $30 \mathrm{~min}$ at $40^{\circ} \mathrm{C}$ to develop color. Absorbance was then read at $765 \mathrm{~nm}$ using the AJI-C03 UV-Vis spectrophotometer. The results were expressed as $\mathrm{mg} / \mathrm{g}$ tannic acid equivalent using the equation based on the calibration curve:

$$
\begin{aligned}
Y & =0.1216 x ; \\
R^{2} & =0.9365,
\end{aligned}
$$

where $x$ is the absorbance and $Y$ is the tannic acid equivalent.

2.4.2. Determination of Total Flavonoids. The flavonoid content was determined by the method used by Oyedemi et al. [24]. Briefly, $0.5 \mathrm{~mL}$ of $2 \% \mathrm{AlCl}_{3}$ was prepared in ethanol. This was then added to $0.5 \mathrm{~mL}$ of the extracts. The mixture was allowed to stand for $60 \mathrm{~min}$ at room temperature and the absorbance was read at $420 \mathrm{~nm}$. The extracts were evaluated at a final concentration of $0.1 \mathrm{mg} / \mathrm{mL}$. The results were 
calculated as quercetin equivalent $(\mathrm{mg} / \mathrm{g})$ using the equation based on the calibration curve:

$$
\begin{aligned}
Y & =0.0255 x ; \\
R^{2} & =0.9812,
\end{aligned}
$$

where $x$ is the absorbance and $Y$ is the quercetin equivalent.

2.4.3. Determination of Total Flavonols. The flavonol content was determined based on the method used by Oyedemi et al. [24]. Briefly, $2 \mathrm{~mL}$ of each plant extract was mixed with $2 \mathrm{~mL}$ of $\mathrm{AlCl}_{3}$ prepared in ethanol. Then $3 \mathrm{~mL}$ of sodium acetate solution $(50 \mathrm{~g} / \mathrm{L})$ was added. The mixture was incubated at $20^{\circ} \mathrm{C}$ for $2.5 \mathrm{~h}$. Absorbance was measured at $440 \mathrm{~nm}$. The total flavonol content was calculated as quercetin $(\mathrm{mg} / \mathrm{g})$ using the following equation based on the calibration curve:

$$
\begin{aligned}
Y & =0.0255 x ; \\
R^{2} & =0.9812,
\end{aligned}
$$

where $x$ is the absorbance and $Y$ is the quercetin equivalent.

2.4.4. Determination of Proanthocyanidin. The total proanthocyanidin was determined using the method described by Oyedemi et al. [24]. A volume of $0.5 \mathrm{~mL}$ of the extract solution was mixed with $3 \mathrm{~mL}$ of $4 \%$ vanillin-methanol solution and $1.5 \mathrm{~mL}$ HCL. The resulting mixture was vortexed and allowed to stand for $15 \mathrm{~min}$ at room temperature and absorbance read at $500 \mathrm{~nm}$. Total proanthocyanidin content was expressed as catechin equivalents $(\mathrm{mg} / \mathrm{g}$ ) using the calibration curve equation:

$$
\begin{aligned}
Y & =0.5825 x ; \\
R^{2} & =0.9277,
\end{aligned}
$$

where $x$ is the absorbance and $Y$ is the catechin equivalent.

2.4.5. Determination of Tannins. Tannin determination was done according to the procedure of Mbaebie et al. [25] with some modifications. $0.2 \mathrm{~g}$ of plant extract was added to $20 \mathrm{~mL}$ of $50 \%$ methanol. This was mixed thoroughly and placed in a water bath at $80^{\circ} \mathrm{C}$ for $60 \mathrm{~min}$. The extract was filtered into a $100 \mathrm{~mL}$ volumetric flask; $20 \mathrm{~mL}$ of distilled water was added, followed by $2.5 \mathrm{~mL}$ of Folin-Ciocalteu reagent and $10 \mathrm{~mL}$ of $17 \% \mathrm{Na}_{2} \mathrm{CO}_{3}$. This was thoroughly mixed together and made up to $100 \mathrm{~mL}$ using distilled water. The mixture was allowed to stand for $20 \mathrm{~min}$ until the bluish-green color developed. The different tannic acid standard solutions concentrations used ranged from 0 to $10 \mathrm{ppm}$. The absorbance of the tannic acid standard solutions and plant extracts were measured after color development at $760 \mathrm{~nm}$ using the AJI-C03 UVVis spectrophotometer. The results were expressed as $\mathrm{mg} / \mathrm{g}$ of tannic acid equivalent using the calibration curve:

$$
\begin{aligned}
Y & =0.0763 x ; \\
R^{2} & =0.9644,
\end{aligned}
$$

where $x$ is the absorbance and $Y$ is tannic acid equivalent.
2.4.6. Determination of Alkaloids. The alkaloid content was determined according to the method of Omoruyi et al. [26]. Briefly, $5 \mathrm{~g}$ of plant extract was mixed with $200 \mathrm{~mL}$ of $10 \%$ acetic acid in ethanol. The mixture was covered and allowed to stand for $4 \mathrm{~h}$. This was filtered and the filtrate was concentrated on a water bath to one-fourth of its original volume. Concentrated ammonium hydroxide was added in drops to the extract until precipitation was completed. The whole solution was allowed to settle and the collected precipitates were washed with dilute ammonium hydroxide and then filtered. The residue collected was dried and weighed. The alkaloid content was determined using the following formula:

$$
\% \text { alkaloid }=\frac{\text { final weight of sample }}{\text { initial weight of extract }} \times 100 \text {. }
$$

2.4.7. Determination of Saponins. The saponin content in the plant extracts was determined using the method of Omoruyi et al. [26]. Briefly, $20 \mathrm{~g}$ of the plant extract was mixed with $200 \mathrm{~mL}$ of $20 \%$ ethanol in a shaker for $30 \mathrm{~min}$ and heated in a water bath at $55^{\circ} \mathrm{C}$ for $4 \mathrm{~h}$ with continuous stirring. The mixture was filtered and the residue was reextracted with another $200 \mathrm{~mL}$ of $20 \%$ ethanol. The combined extracts were reduced to $40 \mathrm{~mL}$ over the water bath at $90^{\circ} \mathrm{C}$. The concentrated solution obtained was then transferred into a $250 \mathrm{~mL}$ separating funnel and extracted twice using $20 \mathrm{~mL}$ diethyl ether. The ether layer was discarded, while the aqueous layer was retained and $60 \mathrm{~mL} n$-butanol was added. The $n$ butanol extracts were washed twice with $10 \mathrm{~mL}$ of $5 \%$ sodium chloride. The remaining solution was heated in a water bath to evaporate and the samples were oven dried at $40^{\circ} \mathrm{C}$ to a constant weight. The percentage saponin content was calculated using the following formula:

$$
\% \text { saponin }=\frac{\text { final weight of sample }}{\text { initial weight of sample }} \times 100 \text {. }
$$

\subsection{In Vitro Antioxidant Analysis}

2.5.1. Antioxidant Assay. The antioxidant activities of the acetone and aqueous extracts of $B$. abyssinica whole plant were determined using DPPH, nitric oxide, reducing power, hydrogen peroxide, ABTS, and lipid peroxidation inhibitory assays.

2.5.2. Ferric Reducing Power Assay. The reducing power of the plant extracts was determined by the method of Mamta et al. [27] with slight modifications. Briefly, different concentrations $(0.025-0.5 \mathrm{mg} / \mathrm{mL})$ of extracts $(0.5 \mathrm{~mL})$ were mixed with $0.5 \mathrm{~mL} 0.2 \mathrm{M}$ phosphate buffer ( $\mathrm{pH} 6.6$ ) and $0.5 \mathrm{~mL} 0.1 \%$ potassium hexacyanoferrate, followed by incubation at $50^{\circ} \mathrm{C}$ in a water bath for $20 \mathrm{~min}$. After incubation, $0.5 \mathrm{~mL} 10 \%$ trichloroacetic acid was added to terminate the reaction. The upper portion of the solution $(1 \mathrm{~mL})$ was mixed with $1 \mathrm{~mL}$ of distilled water and $0.1 \mathrm{~mL} 0.01 \% \mathrm{FeCl}_{3}$ solution added. The reaction mixture was left for $10 \mathrm{~min}$ at room temperature and the absorbance measured at $700 \mathrm{~nm}$ against the appropriate blank solution. A higher absorbance of the reaction mixture indicated greater reducing power. 
2.5.3. DPPH Radical Scavenging Activity Assay. The method of Mamta et al. [27] was used for the determination of DPPH free radical scavenging activity. Briefly, a solution of $0.135 \mathrm{mM}$ DPPH radical in methanol was prepared. $1 \mathrm{~mL}$ of this solution was mixed with $1.0 \mathrm{~mL}$ of each extract $(0.025$ to $0.5 \mathrm{mg} / \mathrm{mL}$ ) and standard drugs (BHT and ascorbic acid) $(0.025$ to $0.5 \mathrm{mg} / \mathrm{mL})$. The reaction mixture was then vortexed thoroughly and left in the dark at room temperature for $30 \mathrm{~min}$. The absorbance of the mixture was measured spectrophotometrically at $517 \mathrm{~nm}$. The actual decrease in absorbance was measured against that of the control. The scavenging ability of the plant extract was then calculated using the following equation:

$$
\begin{aligned}
& \text { DPPH Scavenging activity }(\%) \\
& \quad=\left[\frac{(\text { Abs control }- \text { Abs sample })}{(\text { Abs control })}\right] \times 100,
\end{aligned}
$$

where Abs control is the absorbance of DPPH + methanol and Abs sample is the absorbance of DPPH radical + sample (sample or standard).

2.5.4. Nitric Oxide Scavenging Activity Assay. The modified method described by Oyedemi et al. [24] was used to determine the nitric oxide radical scavenging activity. A volume of $2 \mathrm{~mL}$ of $10 \mathrm{mM}$ of sodium nitroprusside prepared in $0.5 \mathrm{mM}$ phosphate buffer saline $(\mathrm{pH} 7.4)$ was mixed with $0.5 \mathrm{~mL}$ of plant extracts, gallic acid, and BHT individually to make different concentrations from 0.025 to $0.5 \mathrm{mg} / \mathrm{mL}$. The mixture was incubated at $25^{\circ} \mathrm{C}$ for $150 \mathrm{~min}$. Then, $0.5 \mathrm{~mL}$ of incubation solution was then mixed with $0.5 \mathrm{~mL}$ of Griess reagent: $1.0 \mathrm{~mL}$ sulfanilic acid reagent $(0.33 \%$ prepared in $20 \%$ glacial acetic acid at room temperature for $5 \mathrm{~min}$ with $1 \mathrm{~mL}$ of naphthylethylenediamine dichloride $(0.1 \% \mathrm{w} / \mathrm{v}))$. The mixture was incubated at room temperature for $30 \mathrm{~min}$ and absorbance taken at $540 \mathrm{~nm}$. The amount of nitric oxide radicals inhibited by the plant fraction/standard drugs was calculated using the following equation:

$$
\begin{aligned}
& \text { NO radical scavenging activity }(\%) \\
& \qquad=\left[\frac{(\text { Abs control }- \text { Abs sample })}{(\text { Abs control })}\right] \times 100,
\end{aligned}
$$

where Abs control is the absorbance of NO radicals + methanol and Abs sample is the absorbance of NO radical + extract or standard.

2.5.5. Lipid Peroxidation Scavenging Activity Assay. The inhibition of lipid peroxidation in the rat liver homogenate was determined using a modified thiobarbituric acid reactive species (TBARS) assay as described by Murugan and Parimelazhagan [3]. The liver homogenate $(0.5 \mathrm{~mL}, 10 \%$ in distilled water, v/v) and $0.1 \mathrm{~mL}$ of each plant extract were mixed separately in a test tube and the volume was made up to $1 \mathrm{~mL}$ by adding distilled water. Then, $0.05 \mathrm{~mL} \mathrm{FeSO}$ $(0.07 \mathrm{M})$ was added to the above mixture and incubated for $30 \mathrm{~min}$ to induce lipid peroxidation. Thereafter, $1.5 \mathrm{~mL}$ of $20 \%$ acetic acid and $1.5 \mathrm{~mL}$ of $0.8 \%$ TBA (w/v) in $1.1 \%$ sodium dodecyl sulfate and $0.05 \mathrm{~mL} 20 \%$ TCA were added, vortexed, and then heated in a boiling water bath for $60 \mathrm{~min}$. After cooling, $5.0 \mathrm{~mL}$ of butanol was added to each tube and centrifuged at $3000 \mathrm{rpm}$ for $10 \mathrm{~min}$. The absorbance of the organic upper layer was measured at $532 \mathrm{~nm}$. For the blank, $0.1 \mathrm{~mL}$ of distilled water was used in place of the extract. Inhibition (\%) of lipid peroxidation was calculated using the following equation:

$$
\begin{aligned}
\% \text { Inhibition }= & {\left[\frac{(\text { Control OD }- \text { Sample OD })}{\text { Control OD }}\right] } \\
& \times 100 .
\end{aligned}
$$

\subsubsection{Hydrogen Peroxide $\left(\mathrm{H}_{2} \mathrm{O}_{2}\right)$ Radical Scavenging Activity} Assay. The $\mathrm{H}_{2} \mathrm{O}_{2}$ inhibition activity of the extracts was assessed by the method of Gülçin et al. [28]. Briefly, a solution of $4 \mathrm{mM} \mathrm{H}_{2} \mathrm{O}_{2}$ was prepared in phosphate buffer $(0.1 \mathrm{M}$; $\mathrm{pH}$ 7.4) and incubated for $10 \mathrm{~min}$. One milliliter of each plant extract $(0.025$ to $0.5 \mathrm{mg} / \mathrm{mL})$ was added to a $0.6 \mathrm{~mL}$ of hydrogen peroxide solution. The absorbance of the hydrogen peroxide at $230 \mathrm{~nm}$ was determined after 10 min against a blank solution containing phosphate buffer solution without hydrogen peroxide. The positive controls used were BHT ( 0.025 to $0.5 \mathrm{mg} / \mathrm{mL})$ and vitamin $\mathrm{C}(0.025$ to $0.5 \mathrm{mg} / \mathrm{mL})$. The percentage scavenging of hydrogen peroxide of samples was calculated using the following formula:

$$
\begin{aligned}
& \mathrm{H}_{2} \mathrm{O}_{2} \text { inhibition capacity (\%) } \\
& \quad=\left[1-\left(\frac{\mathrm{H}_{2} \mathrm{O}_{2} \text { cons. of sample }}{\mathrm{H}_{2} \mathrm{O}_{2} \text { cons. of blank }}\right)\right] \times 100
\end{aligned}
$$

2.5.7. 2,2'-Azino-bis(3-ethylbenzthiazoline-6-sulfonic acid) (ABTS) Radical Scavenging Assay. The method described by Gülçin et al. [28] was adopted for the determination of ABTS scavenging activity. Briefly, the stock solutions including $7 \mathrm{mM}$ ABTS solution and $2.4 \mathrm{mM}$ potassium persulfate solution were prepared. The working solution was then prepared by mixing the two stock solutions in equal proportions and allowing them to react for $12 \mathrm{~h}$ at room temperature in the dark. The solution was then diluted by mixing $1 \mathrm{~mL} \mathrm{ABTS}^{+}$ solution with $60 \mathrm{~mL}$ of methanol to obtain an absorbance of $0.708 \pm 0.001$ units at $734 \mathrm{~nm}$ using the spectrophotometer. The plant extracts $(1 \mathrm{~mL})$ and their controls were allowed to react with $1 \mathrm{~mL}$ of the $\mathrm{ABTS}^{+}$solution and the absorbance was taken at $734 \mathrm{~nm}$ after $7 \mathrm{~min}$ using the spectrophotometer. The $\mathrm{ABTS}^{+}$scavenging capacity of the extract was then compared with that of the standards. The percentage inhibition was then calculated as follows:

$$
\text { Inhibition } \%=\left[\frac{(A \text { blank }-A \text { sample })}{A \text { blank }}\right] \times 100 \text {, }
$$

where $A$ blank is the absorbance of ABTS radical + methanol used as control and $A$ sample is the absorbance of ABTS radical + sample extract/standard. 
All antioxidant assays were done in triplicate. The activity was expressed as $50 \%$ inhibitory concentration $\left(\mathrm{IC}_{50}\right)$. The lower the $\mathrm{IC}_{50}$ value, the higher the antioxidant activity.

\subsection{In Vitro Anti-Inflammatory Activity}

2.6.1. Protein Denaturation Method. The protein denaturation assay was determined using a modified method as described by Murugan and Parimelazhagan [3]. Briefly, the reaction mixture $(0.5 \mathrm{~mL}$; $\mathrm{pH} 6.3)$ consisted of $0.45 \mathrm{~mL}$ of bovine serum albumin (5\% aqueous solution) and $0.05 \mathrm{~mL}$ of distilled water. The $\mathrm{pH}$ was adjusted to 6.3 using a small amount of $1 \mathrm{~N}$ HCL. $1 \mathrm{~mL}$ of acetone or aqueous extract with final concentrations of $(0.1$ to $0.5 \mathrm{mg} / \mathrm{mL})$ was added to the reaction mixture. These were incubated at $37^{\circ} \mathrm{C}$ for $30 \mathrm{~min}$ and then heated at $57^{\circ} \mathrm{C}$ for $5 \mathrm{~min}$. After cooling the samples, $2.5 \mathrm{~mL}$ of phosphate buffer solution ( $\mathrm{pH} 6.4$ ) was added. Turbidity was measured spectrophotometrically at $660 \mathrm{~nm}$. For the negative control, $0.05 \mathrm{~mL}$ of distilled water and $0.45 \mathrm{~mL}$ of bovine serum albumin were used. Diclofenac sodium with the final concentration of 100, 200, 300, 400, and $500 \mu \mathrm{g} / \mathrm{mL}$ was used as reference drug. The percentage inhibition of protein denaturation was calculated by using the following formula:

$$
\begin{aligned}
& \text { Percentage Inhibition (\%) } \\
& \qquad=\left[\frac{(\text { Abs control }- \text { Abs sample })}{(\text { Abs control })}\right] \times 100 .
\end{aligned}
$$

\subsection{Membrane Stabilizing Activity}

2.7.1. Hypotonic Solution-Induced Rat Erythrocyte Haemolysis. The rat erythrocyte cells were prepared using the method described by Majumder et al. [29]. Briefly, the whole blood was obtained with heparinized syringes from a rat through cardiac puncture. The blood was washed three times with isotonic buffered solution $(154 \mathrm{mM} \mathrm{NaCl})$ in $10 \mathrm{mM}$ sodium phosphate buffer ( $\mathrm{pH}$ 7.4). The blood was centrifuged each time for $10 \mathrm{~min}$ at 13,000 rpm [29].

Membrane stabilizing activity of the extracts was assessed using hypotonic solution-induced rat erythrocyte haemolysis method as described by Majumder et al. [29]. Briefly, the test sample consisted of stock erythrocyte (RBC) suspension $(0.5 \mathrm{~mL})$ mixed with $5 \mathrm{~mL}$ of hypotonic solution $(50 \mathrm{mM}$ $\mathrm{NaCl}$ ) in $10 \mathrm{mM}$ sodium phosphate buffered saline ( $\mathrm{pH} 7.4)$ containing the plant extract or standard drug at concentrations ranging from 0.1 to $1 \mathrm{mg} / \mathrm{mL}$. The control sample consisted of $0.5 \mathrm{~mL}$ of RBC mixed with hypotonic-buffered saline solution alone. The mixtures were incubated for $10 \mathrm{~min}$ at room temperature and centrifuged for $10 \mathrm{~min}$ at 13,000 rpm. The absorbance of the supernatant was measured at $540 \mathrm{~nm}$. The percentage inhibition of haemolysis or membrane stabilization was calculated as follows:

$$
\% \text { Inhibition of haemolysis }=100 \times\left[\mathrm{OD} 1-\frac{\mathrm{OD} 2}{\mathrm{OD} 1}\right] \text {, }
$$

where OD1 is the optical density of hypotonic-buffered saline solution alone and OD2 is the optical density of test sample in hypotonic solution.

\subsection{Antibacterial Analysis}

2.8.1. Microorganisms and Media. The bacteria used in this study were chosen primarily on the basis of their importance as opportunistic pathogens of humans with diabetes mellitus [8-14]. These bacterial strains include Shigella flexneri KZN, Proteus vulgaris, Klebsiella pneumonia ATCC 4352, Staphylococcus aureus, Enterococcus faecalis ATCC 29212, Streptococcus pyogenes, Pseudomonas aeruginosa ATCC 19582, and Serratia marcescens ATCC 9986. The test organisms were obtained from the Department of Biochemistry and Microbiology, University of Fort Hare, South Africa.

Both Mueller-Hinton dextrose agar (MDA) and MuellerHinton dextrose broth (MDB) were prepared according to the manufacturer's instructions. The nutrient agar was suspended in demineralized water, boiled while stirring until completely dissolved. It was autoclaved at $121^{\circ} \mathrm{C}$ for $15 \mathrm{~min}$. The bacteria were maintained at $4^{\circ} \mathrm{C}$ on MDA plates, and the inoculums for the assays were prepared by diluting scraped cell mass in $0.85 \%$ sodium chloride solution, adjusted to $0.5 \mathrm{McFarland}$ standards, and confirmed by spectrophotometric reading at $580 \mathrm{~nm}$ [30]. The cell suspensions were finally diluted 1:100 in broth to give an approximate inoculum of $10^{4} \mathrm{CFU} \mathrm{mL}^{-1}$ as compared with McFarland standard for use in the assays [30].

2.8.2. Antibacterial Susceptibility Assays. Agar diffusion and microdilution methods were used to determine the antibacterial activities of the plant's extracts against the opportunistic bacteria.

2.9. In Vitro Antibacterial Susceptibility Test. The agar well diffusion technique was employed as described by Otang et al. [30] and Prabuseenivasan et al. [13] with some modifications to determine the antibacterial susceptibility test. Briefly, $100 \mu \mathrm{L}$ of $0.5 \mathrm{McF}$ arland solutions of bacterial strain cultures in $0.85 \%$ sterile distilled water (SDW) was placed over the surface of an agar plate and spread using a sterile inoculation loop. Four wells were cut in each agar plate with a cooled, flamed cork borer of $5 \mathrm{~mm}$ diameter, and the agar plugs removed with a sterile needle. $50 \mu \mathrm{L}$ of the positive control drug Amoxicillin $(0.0125 \mathrm{mg} / \mathrm{mL})$ and $50 \mu \mathrm{L}$ of the acetone extract at concentration of $50 \mathrm{mg} / \mathrm{mL}$ were added in the first and second wells, respectively. In the third and fourth wells, $50 \mu \mathrm{L}$ of the aqueous extract $(50 \mathrm{mg} / \mathrm{mL})$ and nutrient broth (negative control) were added, respectively. The culture plates were then incubated at $37^{\circ} \mathrm{C}$, and the results were observed after $24 \mathrm{~h}$. The clear zone around each well was measured in $\mathrm{mm}$, indicating the activity of the plant extract against the bacterial organisms.

2.10. Minimum Inhibitory Concentration (MIC) Assay. The broth microdilution method using 96-well microtiter plates was employed to determine the minimum inhibitory concentration (MIC) of the plant extracts [30]. Briefly, $120 \mu \mathrm{L}$ of SDW was added into each well of the first $(\mathrm{A})$ and last $(\mathrm{H})$ rows and also into all the wells of the last column. Then, $120 \mu \mathrm{L}$ of nutrient broth (NB) was added into each well of the second row (B). $150 \mu \mathrm{L}$ of $\mathrm{NB}$ was then added into 
the remaining wells of the first column and $100 \mu \mathrm{L}$ into the rest of the wells from the second column rightward. Fifty microliters of the plant extract was then added into the third well of the first column while $50 \mu \mathrm{L}$ of the positive (Amoxicillin) and negative control (SDW) was separately added into the remaining wells of the first column. A twofold serial dilution was done by mixing the contents in each well of the first column (starting from the third row) and transferring $100 \mu \mathrm{L}$ into the second well of the same row and the procedure was repeated up to the 11th well of the same row and the last $100 \mu \mathrm{L}$ from the 11th well was discarded. Various concentrations of the plant extracts ranging from $5 \mathrm{mg} / \mathrm{mL}$ to $0.005 \mathrm{mg} / \mathrm{mL}$ were prepared in the wells, following the twofold dilution method.

Thereafter, $20 \mu \mathrm{L}$ of $0.5 \mathrm{McF}$ arland bacteria suspensions was inoculated into the wells except those which contained SDW. The growth of the bacteria was measured by determining the absorbance at $620 \mathrm{~nm}$ with an automatic ELISA microplate reader (SynergyMx BiotekR, USA) before and after incubation. The plates were incubated at $37^{\circ} \mathrm{C}$ for $24 \mathrm{~h}$. The MIC was defined and recorded as the lowest concentration of the test antibacterial agent that had inhibition on $50 \%$ bacterial growth. This was determined by assessing growth by calculating the difference in absorbance between the test wells and the control wells that had the broth and antimicrobial agent alone without the test bacteria [30].

\section{Results}

3.1. Phytochemical Content. The results showed the presence of some of the assessed phytochemical constituents in varying amounts in both extracts. The aqueous extract showed significantly higher amounts of all the phytochemical constituents present than the acetone extract except total flavanols and saponin contents $(P<0.05)$ (Figure 1$)$.

3.2. Antioxidant Activities of the Extracts. The acetone and aqueous extracts showed remarkable percentage inhibition activity in all the free radical scavenging in vitro models used in the present study. The antioxidant potentials of the plant extracts were estimated from their ability to reduce $\mathrm{Fe}^{3+}$ to $\mathrm{Fe}^{2+}$ which was concentration-dependent of the extracts/reference standard (Figure 2). The trend of the reducing potential of both the extracts was significantly lower than that of BHT followed by vitamin C except at $0.05 \mathrm{mg} / \mathrm{mL}$ in which acetone extract inhibitory potential was significantly similar to BHT $(P<0.05)$ (Figure 2$)$. The $\mathrm{IC}_{50}$ values show that the aqueous extract had the highest Fe reducing potential compared to acetone extract but less activity when compared to the two standards (Table 1).

The results from a series of concentration ranging from 0.025 to $0.5 \mathrm{mg} / \mathrm{mL}$ were used to determine the concentration required to attain $50 \%$ DPPH radical scavenging effect $\left(\mathrm{IC}_{50}\right)$. A lower $\mathrm{IC}_{50}$ value indicates higher scavenging activity [24]. The $\mathrm{IC}_{50}$ values of the tested extracts/standards were in the following order: vitamin $\mathrm{C}<$ acetone extract $<$ BHT $<$ rutin $\leq$ aqueous extract (Table 1 ). Both extracts showed scavenging activity in a dose-dependent manner $(P<$ 0.05) (Figure 3).

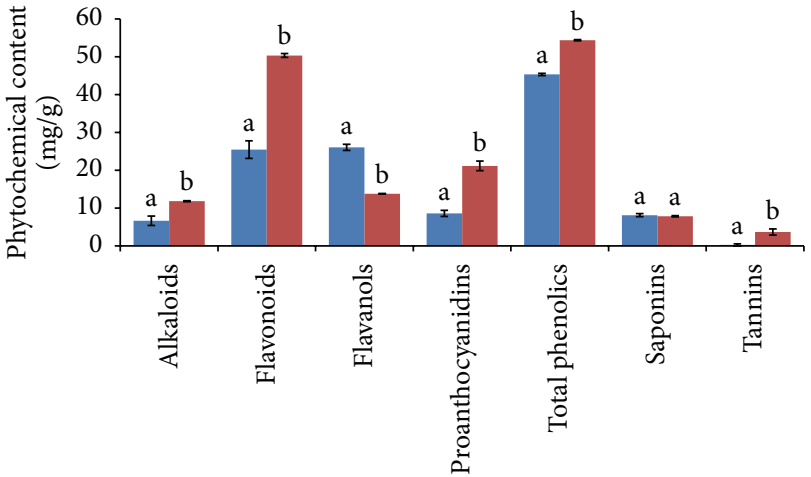

Phytochemical constituent

$$
\begin{aligned}
& \text { Acetone extract } \\
& \text { Aqueous extract }
\end{aligned}
$$

FIGURE 1: Phytochemical constituents in the acetone and aqueous extracts of B. abyssinica. Bar graphs with different letter superscript within the same constituent are significantly different $(P<0.05)$.

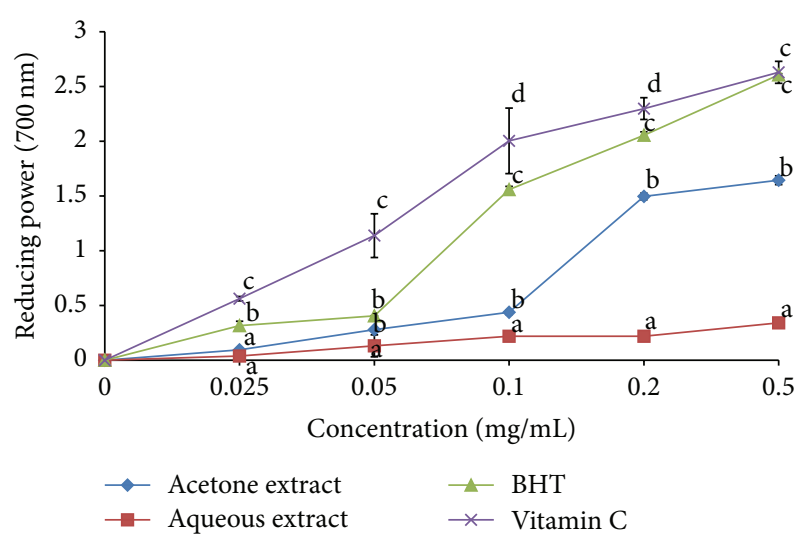

FIGURE 2: Reducing power of the acetone and aqueous extracts of Bulbine abyssinica. Line points with different letter superscript within the same concentration are significantly different $(P<0.05)$.

The nitric oxide radical scavenging activity of the plant species was revealed as the \% inhibition of nitric oxide (Figure 4). The scavenging activities were concentrationdependent. The $\mathrm{IC}_{50}$ value determination indicates that the scavenging activity was significantly higher with vitamin C, followed by aqueous extract and then rutin and acetone $(P<$ 0.05) (Figure 4) (Table 1).

The scavenging of lipid peroxides by $B$. abyssinica extracts, BHT, gallic acid, and vitamin $\mathrm{C}$ is presented in Figure 5 . The $\%$ inhibition of lipid peroxides by the extract and standards was recorded in significantly increasing order: vitamin $\mathrm{C}>\mathrm{BHT}>$ gallic acid $>$ aqueous extract $>$ acetone extract $(P<0.05)$. The $\mathrm{IC}_{50}$ value indicates that acetone extract had the highest inhibitory potential followed by aqueous extract, rutin, BHT, and then vitamin $\mathrm{C}$ with the lowest activity (Table 1). 
TABLE 1: Scavenging and inflammation inhibitory activities of acetone and aqueous extracts of B. abyssinica.

\begin{tabular}{|c|c|c|c|c|c|c|c|c|c|c|c|c|c|c|c|c|}
\hline \multirow{2}{*}{$\begin{array}{l}\text { Activity } \\
\text { Samples }\end{array}$} & \multicolumn{2}{|c|}{ A } & \multicolumn{2}{|c|}{ B } & \multicolumn{2}{|c|}{$\mathrm{C}$} & \multicolumn{2}{|c|}{$\mathrm{D}$} & \multicolumn{2}{|c|}{$\mathrm{E}$} & \multicolumn{2}{|c|}{$\mathrm{F}$} & \multicolumn{2}{|c|}{ G } & \multicolumn{2}{|c|}{$\mathrm{H}$} \\
\hline & $\mathrm{IC}_{50}{ }^{\mathrm{a}}$ & $R^{2^{\mathrm{b}}}$ & $\mathrm{IC}_{50}{ }^{\mathrm{a}}$ & $R^{2^{\mathrm{b}}}$ & $\mathrm{IC}_{50}{ }^{\mathrm{a}}$ & $R^{2^{\mathrm{b}}}$ & $\mathrm{IC}_{50}{ }^{\mathrm{a}}$ & $R^{2^{\mathrm{b}}}$ & $\mathrm{IC}_{50}{ }^{\mathrm{a}}$ & $R^{2^{\mathrm{b}}}$ & $\mathrm{IC}_{50}{ }^{\mathrm{a}}$ & $R^{2^{\mathrm{b}}}$ & $\mathrm{IC}_{50}{ }^{\mathrm{a}}$ & $R^{2^{\mathrm{b}}}$ & $\mathrm{IC}_{50}{ }^{\mathrm{a}}$ & $R^{2^{\mathrm{b}}}$ \\
\hline Acetone extract & 1.25 & 78.3 & 0.19 & 79.6 & 0.23 & 89.9 & 0.04 & 88.4 & 0.18 & 83.6 & 0.14 & 86.2 & 0.22 & 74.3 & 0.51 & 90.1 \\
\hline Aqueous extract & 0.19 & 79.7 & 0.26 & 99.7 & 0.14 & 85.9 & 0.24 & 99.8 & 1.61 & 92.2 & 0.21 & 87.8 & 0.33 & 71.5 & 0.33 & 72.2 \\
\hline BHT & 0.18 & 88.7 & 0.2 & 90.4 & - & - & 0.25 & 99.4 & 2.04 & 84.8 & 0.16 & 87.3 & - & - & - & - \\
\hline Vitamin C & 0.12 & 85.3 & 0.07 & 89.7 & 0.09 & 84.9 & 0.22 & 93.1 & 2.21 & 96.8 & - & - & - & - & - & - \\
\hline Rutin & - & - & 0.26 & 81.4 & 0.23 & 91.1 & - & - & - & - & 0.18 & 81.3 & - & - & - & - \\
\hline Gallic acid & - & - & - & - & - & - & - & - & 1.67 & 76.7 & - & - & - & - & - & - \\
\hline Diclofenac sodium & - & - & - & - & - & - & - & - & - & - & - & - & 0.31 & 91.9 & 0.48 & 81.2 \\
\hline
\end{tabular}

$\mathrm{A}$ is reducing power; B is DPPH scavenging activity; $\mathrm{C}$ is nitric oxide scavenging activity; D is hydrogen peroxide scavenging activity; $\mathrm{E}$ is lipid peroxide scavenging activity; $\mathrm{F}$ is ABTS scavenging activity; $\mathrm{G}$ is protein denaturation inhibitory activity; and $\mathrm{H}$ is membrane lysis inhibitory activity. ${ }^{\mathrm{a}} \mathrm{IC}_{50}$ is defined as the concentration $(\mathrm{mg} / \mathrm{mL})$ sufficient to obtain $50 \%$ of a maximum scavenging capacity. ${ }^{\mathrm{b}}$ Coefficient of determination. Values are obtained from regression lines with $95 \%$ confidence level. — indicates values not determined.

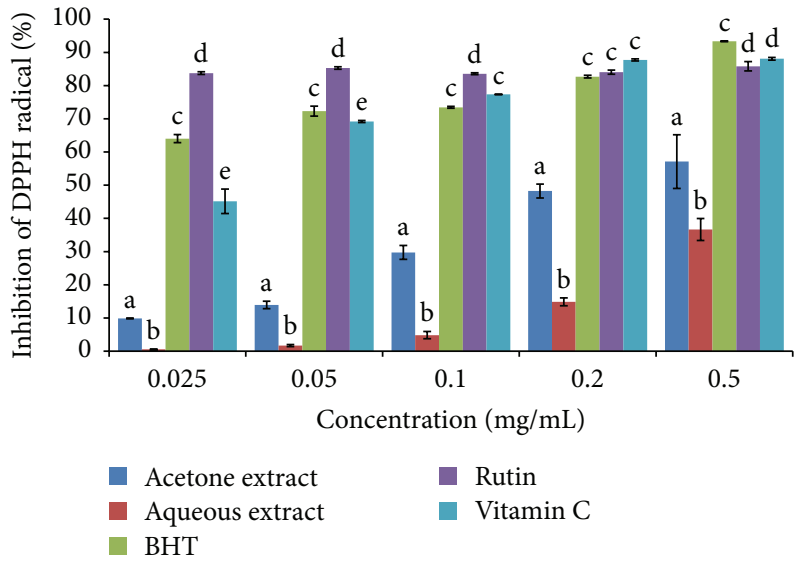

FIGURE 3: DPPH radical scavenging activity of the acetone and aqueous extracts of $B$. abyssinica. Bar graphs with different letter superscript within the same concentration are significantly different $(P<0.05)$

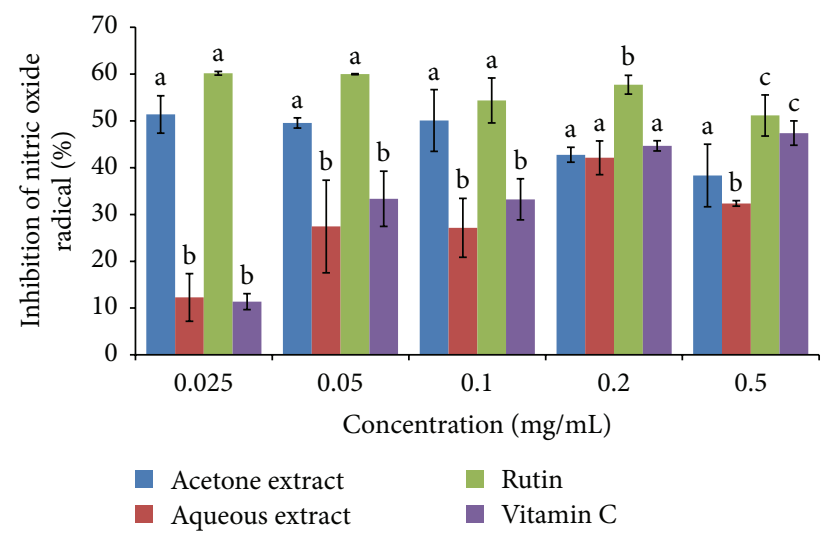

FIGURE 4: Nitric oxide radical scavenging activity of the acetone and aqueous extracts of $B$. abyssinica. Bar graphs with different letter superscript within the same concentration are significantly different $(P<0.05)$.

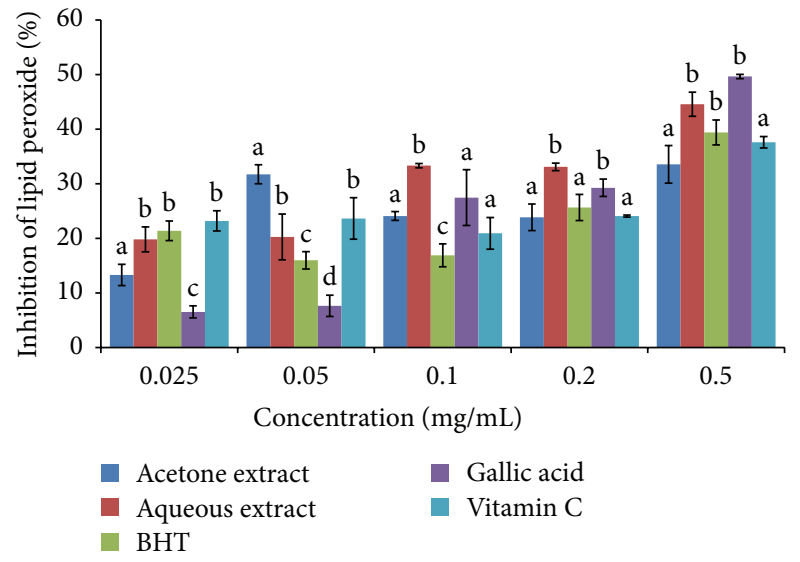

FIGURE 5: Lipid peroxidation scavenging activity of the acetone and aqueous extracts of $B$. abysinica. Bar graphs with different letter superscript within the same concentration are significantly different $(P<0.05)$.

The $\mathrm{IC}_{50}$ values for $\mathrm{H}_{2} \mathrm{O}_{2}$ scavenging activity for acetone extract, aqueous extract, $\mathrm{BHT}$, and vitamin $\mathrm{C}$ were $0.04,0.24$, 0.25 , and $0.22 \mathrm{mg} / \mathrm{mL}$, respectively (Table 1 ). The $\mathrm{H}_{2} \mathrm{O}_{2}$ scavenging activity of both plant species and standards decreased with increasing concentration (Figure 6). The acetone extract showed significantly higher scavenging potential than aqueous extract in all concentrations, except at $0.05 \mathrm{mg} / \mathrm{mL}$. The scavenging activity of both plant extracts was significantly higher than those of the standards $(P<0.05)$ (Figure 6).

The percentage inhibition of ABTS radical by the species is shown in Figure 7. The \% inhibition of ABTS by the plant and the standards was concentration-dependent and compared favorably with both BHT and rutin. The scavenging activity was in the following order: BHT $>$ rutin $>$ acetone extract $>$ aqueous extract. The acetone extract's activity was significantly higher than the two standards while aqueous extract showed significantly lower inhibitory activity 
TABle 2: Protein denaturation activity of acetone and aqueous extracts of B. abyssinica.

\begin{tabular}{lccc}
\hline Concentration $(\mu \mathrm{g} / \mathrm{mL})$ & $\begin{array}{c}\text { Standard (diclofenac sodium) } \\
\text { Mean \% inhibition } \pm \text { SD }\end{array}$ & $\begin{array}{c}\text { Acetone extract of B. abyssinica } \\
\text { Mean \% inhibition } \pm \text { SD }\end{array}$ & $\begin{array}{c}\text { Aqueous extract of B. abyssinica } \\
\text { Mean \% inhibition } \pm \text { SD }\end{array}$ \\
\hline 500 & $98.68 \pm 2.28^{\mathrm{a}}$ & $85.09 \pm 0.76^{\mathrm{b}}$ & $67.98 \pm 11.50^{\mathrm{c}}$ \\
400 & $95.61 \pm 0.76^{\mathrm{a}}$ & $79.39 \pm 0.75^{\mathrm{b}}$ & $78.95 \pm 2.63^{\mathrm{b}}$ \\
300 & $87.72 \pm 1.52^{\mathrm{a}}$ & $72.81 \pm 5.93^{\mathrm{a}}$ & $85.09 \pm 21.43^{\mathrm{a}}$ \\
200 & $88.16 \pm 2.01^{\mathrm{a}}$ & $71.06 \pm 2.28^{\mathrm{b}}$ & $93.86 \pm 2.01^{\mathrm{a}}$ \\
100 & $83.77 \pm 0.76^{\mathrm{a}}$ & $30.70 \pm 5.32^{\mathrm{b}}$ & $86.40 \pm 0.76^{\mathrm{a}}$ \\
\hline
\end{tabular}

Data expressed as means $\pm \mathrm{SD} ; n=3$; values along a row with different superscripts are significantly different $(P<0.05)$.

TABLE 3: Effect of acetone and aqueous extracts of B. abyssinica on erythrocyte membrane haemolysis.

\begin{tabular}{lccc}
\hline Concentration $(\mu \mathrm{g} / \mathrm{mL})$ & $\begin{array}{c}\text { Standard (diclofenac sodium) } \\
\text { Mean \% inhibition } \pm \text { SD }\end{array}$ & $\begin{array}{c}\text { Acetone extract of B. abyssinica } \\
\text { Mean \% inhibition } \pm \text { SD }\end{array}$ & $\begin{array}{c}\text { Aqueous extract of B. abyssinica } \\
\text { Mean \% inhibition } \pm \text { SD }\end{array}$ \\
\hline 1000 & $89.19 \pm 1.78^{\mathrm{a}}$ & $70.72 \pm 0.77^{\mathrm{b}}$ & $79.50 \pm 1.41^{\mathrm{c}}$ \\
500 & $79.95 \pm 6.14^{\mathrm{a}}$ & $56.31 \pm 0.78^{\mathrm{b}}$ & $75 \pm 1.17^{\mathrm{a}}$ \\
400 & $79.51 \pm 2.17^{\mathrm{a}}$ & $34.69 \pm 0.79^{\mathrm{b}}$ & $62.61 \pm 2.17^{\mathrm{c}}$ \\
300 & $63.06 \pm 2.81^{\mathrm{a}}$ & $30.63 \pm 0.39^{\mathrm{b}}$ & $44.14 \pm 0.78^{\mathrm{c}}$ \\
200 & $58.56 \pm 1.03^{\mathrm{a}}$ & $31.08 \pm 0.68^{\mathrm{b}}$ & $41.89 \pm 1.35^{\mathrm{c}}$ \\
100 & $58.55 \pm 0.78^{\mathrm{a}}$ & $21.4 \pm 0.78^{\mathrm{b}}$ & $16.44 \pm 0.39^{\mathrm{c}}$ \\
\hline
\end{tabular}

Data expressed as means $\pm \mathrm{SD} ; n=3$; values along a row with different superscripts are significantly different $(P<0.05)$.

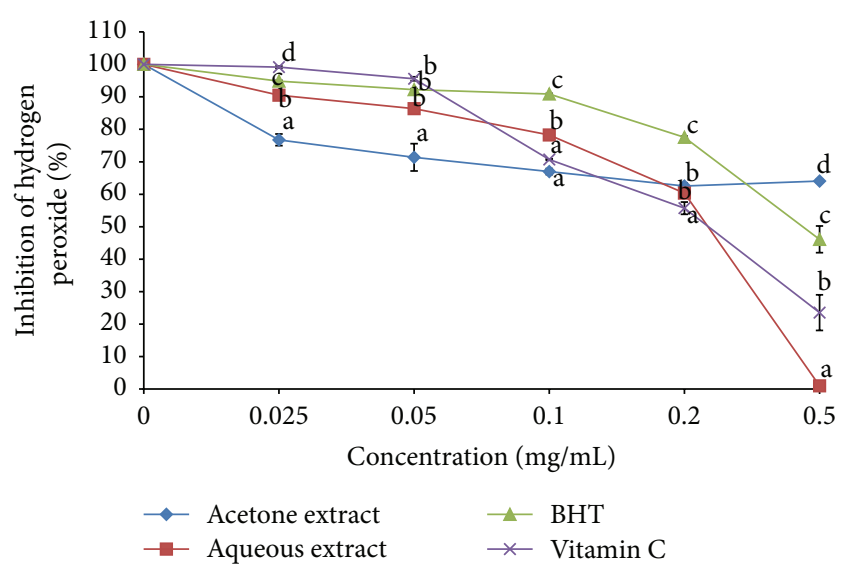

FIGURE 6: Hydrogen peroxide radical scavenging activity of the acetone and aqueous extracts of B. abyssinica. Line points with different letter superscript within the same concentration are significantly different $(P<0.05)$.

$(P<0.05)$ (Figure 7$)$. The $\mathrm{IC}_{50}$ values of the plant extracts/ standards were in the following increasing order: acetone extract $<$ BHT $<$ rutin $<$ aqueous extract (Table 1 ).

The results show that the free radical scavenging potential of the plant extracts varies according to free radical species. Both the acetone and aqueous extracts showed high activity for the radical scavenging potentials with acetone extract exhibiting the highest potentials in all assay models except with reducing power and nitric oxide scavenging ability.

3.3. In Vitro Anti-Inflammatory Activity. Acetone extract protected the albumin from denaturation in a dose-dependent manner which was comparable to the standard drug, except

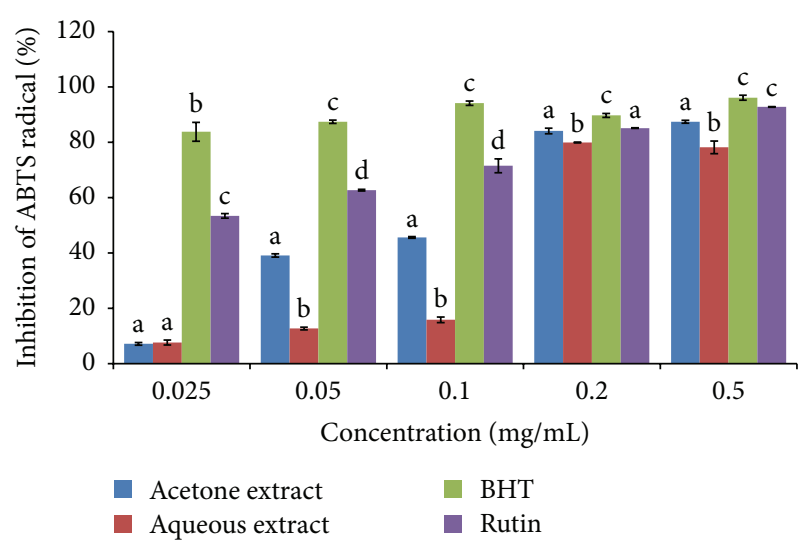

FIGURE 7: ABTS radical scavenging activity of the acetone and aqueous extracts of $B$. abyssinica. Bar graphs with different letter superscript within the same concentration are significantly different $(P<0.05)$.

at the concentration of $300 \mu \mathrm{g} / \mathrm{mL}$. The aqueous extract also shows significant protein denaturation inhibition with increase in the concentration (100 to $300 \mu \mathrm{g} / \mathrm{mL}$ ) when compared to the standard drug. However, it showed a significant decrease from $400 \mu \mathrm{g} / \mathrm{mL}(P<0.05)$ (Table 2$)$.

The acetone and aqueous extracts' protection against erythrocyte membrane lysis is significantly lower than the standard drug in a dose-dependent manner, except for the aqueous extract at $500 \mu \mathrm{g} / \mathrm{mL}$ which was similar in inhibition $(P<0.05)$ (Tables 1 and 3$)$. The $\mathrm{IC}_{50}$ values indicate that acetone extract exhibited the highest protein denaturation inhibitory effect compared to the aqueous extract while the aqueous extract exhibited the highest membrane lysis protection (Table 1). 
TABLE 4: Inhibition zone diameters caused by acetone and aqueous extracts of B. abyssinica $(50 \mathrm{mg} / \mathrm{mL})$ against the tested opportunistic bacteria.

\begin{tabular}{|c|c|c|c|c|c|c|c|c|}
\hline \multirow{2}{*}{ Sample } & \multicolumn{8}{|c|}{ Inhibition zone diameter (mm) } \\
\hline & Sf & $\mathrm{Pa}$ & Sa & Ef & $\mathrm{Kp}$ & $\mathrm{Sp}$ & $\mathrm{Pv}$ & $\mathrm{Sm}$ \\
\hline $\begin{array}{l}\text { Acetone } \\
\text { extract }\end{array}$ & $23.33 \pm 3.06_{1}{ }^{a}$ & $20 \pm 3.46_{1}{ }^{\mathrm{a}}$ & $35 \pm 2.65_{2}{ }^{\mathrm{a}}$ & $24 \pm 3.46_{1}{ }^{\mathrm{a}}$ & $14.67 \pm 0.58_{3}{ }^{\mathrm{a}}$ & $14.33 \pm 1.53_{3}{ }^{a}$ & $20.33 \pm 0.58_{1}{ }^{\mathrm{a}}$ & 0 \\
\hline $\begin{array}{l}\text { Aqueous } \\
\text { extract }\end{array}$ & $17.67 \pm 6.03_{1}^{a}$ & $12 \pm 1.73_{1}{ }^{\mathrm{b}}$ & $41 \pm 3.46_{2}^{b}$ & $14.67 \pm 6.35_{1}^{b}$ & $16 \pm 1.73_{1}^{\mathrm{a}}$ & $16.67 \pm 2.08_{1}{ }^{a}$ & $18.67 \pm 1.15_{1}^{a}$ & 0 \\
\hline Control & $22.67 \pm 2.31_{1}{ }^{a}$ & $27 \pm 3.46_{1}{ }^{\mathrm{c}}$ & $30.67 \pm 3.51_{2}{ }^{c}$ & $26.67 \pm 3.79_{1}^{a}$ & $23.67 \pm 0.58_{1}{ }^{b}$ & $38.33 \pm 1.53_{3}^{b}$ & $41.67 \pm 2.89_{4}^{b}$ & $32.56 \pm 2.44_{2}$ \\
\hline
\end{tabular}

The bacteria isolates are denoted as Sf (Shigella flexneri), Pa (Pseudomonas aeruginosa), Sa (Staphylococcus aureus), Ef (Enterococcus faecalis), Kp (Klebsiella pneumonia), Sp (Streptococcus pyogenes), Pv (Proteus vulgaris), and Sm (Serratia marcescens). Data expressed as means $\pm \mathrm{SD} ; n=3$; values along a row with different subscripts are significantly different $(P<0.05)$. Mean with the different superscript in the same column is significantly different $(P<0.05)$. Concentration of positive control is $0.013 \mathrm{mg} / \mathrm{mL}$.

TABLE 5: Minimum inhibitory concentrations (MIC) of acetone and aqueous extracts of B. abyssinica against the tested opportunistic bacteria.

\begin{tabular}{|c|c|c|c|c|c|c|c|c|}
\hline \multirow{2}{*}{ Sample } & \multicolumn{8}{|c|}{$\mathrm{MIC}(\mathrm{mg} / \mathrm{mL})$} \\
\hline & Sf & $\mathrm{Pa}$ & $\mathrm{Sa}$ & Ef & Kp & $\mathrm{Sp}$ & $\mathrm{Pv}$ & $\mathrm{Sm}$ \\
\hline Acetone extract & $0.63_{1}^{a}$ & $0.31_{2}^{a}$ & $0.31_{2}^{a}$ & $0.31_{2}{ }^{a}$ & $2.5_{3}{ }^{\mathrm{a}}$ & $>5_{4}{ }^{a}$ & $1.25_{5}^{\mathrm{a}}$ & - \\
\hline Aqueous extract & $0.31_{1}^{b}$ & $>5_{2}^{\mathrm{b}}$ & $0.078_{3}{ }^{b}$ & $1.25_{4}^{\mathrm{b}}$ & $2.5_{5}^{\mathrm{a}}$ & $5_{2}^{\mathrm{a}}$ & $0.63_{6}{ }^{b}$ & - \\
\hline Control & $0.16_{1}{ }^{\mathrm{c}}$ & $0.16_{1}{ }^{\mathrm{c}}$ & $0.16_{1}{ }^{\mathrm{c}}$ & $0.16_{1}{ }^{\mathrm{c}}$ & $0.16_{1}^{\mathrm{b}}$ & $0.16_{1}{ }^{\mathrm{b}}$ & $1.25_{2}{ }^{\mathrm{a}}$ & $0.16_{1}$ \\
\hline
\end{tabular}

The bacteria isolates are denoted as Sf (Shigella flexneri), $\mathrm{Pa}$ (Pseudomonas aeruginosa), Sa (Staphylococcus aureus), Ef (Enterococcus faecalis), Kp (Klebsiella pneumonia), Sp (Streptococcus pyogenes), Pv (Proteus vulgaris), and Sm (Serratia marcescens). "-" denotes values not determined. Data expressed as means $\pm \mathrm{SD} ; n=3$; values along a row with different subscripts are significantly different $(P<0.05)$. Mean with the different superscript in the same column is significantly different $(P<0.05)$. Concentration of positive control is $0.013 \mathrm{mg} / \mathrm{mL}$.

3.4. Antibacterial Analysis. The species was tested against eight diabetic status opportunistic bacteria. The results show that the acetone and aqueous extracts were active against the growth of all organisms except $S$. marcescens. The zones of inhibition were varying from 12 to $41 \mathrm{~mm}$ (Table 4).

The highest activity against the tested bacteria was obtained with the aqueous extract which showed inhibition zones diameters of 41,19 , and $18 \mathrm{~mm}$ against $S$. aureus, $P$. vulgaris, and S. flexneri, respectively (Table 4), while with acetone extract's inhibitory activity was with inhibition zones diameters of $35,24,23$, and $20 \mathrm{~mm}$ against $S$. aureus, $E$. faecalis, S. flexneri, and P. vulgaris, respectively. The lowest activity obtained with aqueous extract showed inhibition zone diameter of $12 \mathrm{~mm}$ against $P$. aeruginosa, while with acetone extract activity against $S$. pyogenes showed the lowest inhibition zones diameter of $14 \mathrm{~mm}$ (Table 4). Based on the overall mean inhibition diameters, acetone extract showed significantly more inhibitory activity with overall mean inhibition diameters of $18.95 \pm 9.38 \mathrm{~mm}$ than aqueous extract with $17.09 \pm 10.60 \mathrm{~mm}$ inhibition diameter $(P<0.05)$.

The varying concentrations between 5 and $0.005 \mathrm{mg} / \mathrm{mL}$ of the plant extracts were tested in order to determine their MICs (Table 5). The lowest MIC $(0.31 \mathrm{mg} / \mathrm{mL})$ with acetone extract was observed against $S$. aureus, $P$. aeruginosa, and $E$. faecalis. The aqueous extract showed the lowest MIC activity against S. aureus $(0.078 \mathrm{mg} / \mathrm{mL})$ and $S$. flexneri $(0.31 \mathrm{mg} / \mathrm{mL})$. The acetone extract (MIC of $1.25 \mathrm{mg} / \mathrm{mL}$ ) showed significantly similar activity with the standard drug/control (Amoxicillin) against $P$. vulgaris $(P<0.05)$ (Table 5).

\section{Discussion}

The results obtained in the present study revealed the presence of considerable amounts of total phenols, flavonoids, flavanols, proanthocyanidins, and alkaloids in acetone and aqueous extracts with the latter extracting more amounts (Figure 1). The aqueous solvent extracted more of the phytochemicals indicating differences in the extracting capacity of the two solvents. The in vitro antioxidant model assays revealed that the plant species possesses free radical scavenging potential varying with free radical species (Figures 2-7). The antioxidant potential of this species could be postulated by the presence of these phytochemicals. Phenolic compounds and flavonoids are the major constituents in most plants reported to possess free radical scavenging activity [31]. The mode of action of phenolic compounds in free radical moping activity is via inactivating lipid free radicals or by preventing the decomposition of hydroperoxides into free radicals [32]. Flavonoids possessing hydroxyl groups mediate their antioxidant effects by chelating metal ions and quenching or protecting antioxidant defenses [32].

Proanthocyanidins are a class of nutrients that belong to the flavonoid family; hence their mechanism of action as antioxidants is the same as that of flavonoids [33]. These exert their activity via inactivating the iron ions by chelating and suppressing the superoxide-driven Fenton reaction, which is the most important source of reactive oxygen species [33].

Alkaloids have also been shown to have antioxidant properties via alleviating $\mathrm{H}_{2} \mathrm{O}_{2}$-induced oxidative damage [34]. 
Flavanols also have free radical scavenging potential through lipid peroxidation inhibition with its activity due to the sugar substitutions in the phenolic C ring [34]. Saponins possess antioxidant potential through hydrogen peroxide scavenging capability [35]. Tannins are potent antioxidants, whose bioactivities are through chelating metal ions such as Fe (II) and interfering with one of the reaction steps in the Fenton reaction and thereby retard oxidation. Tannins also inhibit lipid peroxidation via the inhibition of cyclooxygenase enzyme [35].

Protein denaturation and membrane leakage are the main cause of inflammatory processes implicated in pathogenesis of diseases and infections [3]. This plant species exhibited remarkable protein denaturation inhibitory activity while offering high protection against erythrocyte membrane lysis hence indicating anti-inflammatory potential (Tables 1, 2, and 3 ). This bioactivity could be postulated due to the presence of these phytochemical constituents which may be capable of inhibiting the inflammation processes [3]. Studies have shown that phenolics and flavonoids act as excellent antiinflammatory agents. Flavonoids are reported to have antiinflammatory activities and act through inhibiting a number of immune system inflammatory mediators [36]. Alkaloids may also inhibit inflammation through blocking the cyclooxygenase and lipoxygenase metabolic pathways of arachidonic acid metabolism [37]. Proanthocyanidins also possess anti-inflammatory and immunomodulatory properties which could help to prevent oxidative stress related diseases [29].

The acetone and aqueous extracts of B. abyssinica showed activity against growth of some pathogenic bacteria that cause infections associated with diabetic status (Tables 4 and 5). Both plant extracts greatly inhibited the growth of $S$. aureus, P. vulgaris, S. flexneri, and E. faecalis (Tables 4 and 5). The antibacterial activity could also be attributed by the presence of some chemical constituents identified in the plant fractions [38].

The total phenolics and the highest phytochemicals have been reported to have antibacterial activity [38]. Alkaloids and flavonoids also possess antibacterial activity. The antibacterial mechanisms of action of selected flavonoids are attributed to inhibition of DNA gyrase, cytoplasmic membrane function, and licochalcones $\mathrm{A}$ and $\mathrm{C}$ energy metabolism [39]. Proanthocyanidins are also known to be targets as antibacterial agents [40].

These findings also showed some trace amounts of saponins and tannins (Figure 1). Antibacterial activity of saponins from different plant sources has been widely reported [41]. Tannins act as natural antibiotics through preventing lipid peroxidation or by iron deprivation, hydrogen bonding, or specific interactions with vital proteins such as enzymes in microbial cells [41]. Tannins have been further shown to confer inhibitory growth activity against $S$. aureus, $P$. aeruginosa, and E. faecalis [42]. Therefore, these classes of phytochemical constituents are promising prospects for future synthesis of new antibacterial agents [42].

Even though these phytochemical constituents are known to have antioxidant, anti-inflammatory, and antibacterial properties, it is postulated that they could be acting singly or in combinations to potentiate the plants' potentials [43]. Therefore, it is crucial to isolate and elucidate the bioactive compounds and determine their pharmacological properties. This could facilitate the finding of novel antioxidant, antibacterial, and anti-inflammatory agents.

The presence of phytochemicals such as total phenolics, alkaloids, flavonoids, saponins, tannins, and proanthocyanidins in $B$. abyssinica provides some scientific evidence for the biological activities and also accounts for the multipharmacological use of this plant in traditional medicine. The plant extracts showed good antioxidant, anti-inflammatory, and antibacterial activities indicating that this plant is a good source of these agents.

\section{Conflict of Interests}

The authors have no conflict of interests.

\section{Authors' Contribution}

The study was conceived and carried out by Cromwell Mwiti Kibiti and Anthony Jide Afolayan. The collection and extraction of plant materials were carried out by Cromwell Mwiti Kibiti. The design and coordination of the experiment and statistical analysis were done by Cromwell Mwiti Kibiti and Anthony Jide Afolayan. Cromwell Mwiti Kibiti and Anthony Jide Afolayan wrote the paper. All authors have read and approved the final paper.

\section{Acknowledgment}

This research was supported by grants from Govan Mbeki Research and Development Centre, University of Fort Hare, South Africa.

\section{References}

[1] K. Rangasamy and E. Namasivayam, "In vitro antioxidant and free radical scavenging activity of isolongifolene," Asian Journal of Biological Sciences, vol. 7, pp. 13-23, 2014.

[2] B. Uttara, A. V. Singh, P. Zamboni, and R. T. Mahajan, "Oxidative stress and neurodegenerative diseases: a review of upstream and downstream antioxidant therapeutic options," Current Neuropharmacology, vol. 7, no. 1, pp. 65-74, 2009.

[3] R. Murugan and T. Parimelazhagan, "Comparative evaluation of different extraction methods for antioxidant and anti-inflammatory properties from Osbeckia parvifolia Arn.- an in vitro approach," Journal of King Saud University-Science, vol. 26, no. 4, pp. 267-275, 2014.

[4] E. Umapathy, E. J. Ndebia, A. Meeme, B. Adam, P. Menziwa, and B. N. Nkeh-Chungag, "An experimental evaluation of Albu casetosa aqueous extract on membrane stabilization, protein denaturation and white blood cell migration during acute inflammation," Journal of Medicinal Plants Research, vol. 4, pp. 785-795, 2010.

[5] K. Skarbez, Y. Priestley, M. Hoepf, and S. B. Koevary, "Comprehensive review of the effects of diabetes on ocular health," Expert Review of Ophthalmology, vol. 5, no. 4, pp. 557-577, 2010. 
[6] J. Casqueiro, J. Casqueiro, and C. Alves, "Infections in patients with diabetes mellitus: a review of pathogenesis," Indian Journal of Endocrinology and Metabolism, vol. 16, no. 7, pp. S27-S36, 2012.

[7] M. S. Balachandar, P. Pavkoviç, and Ž. Metelko, "Kidney infections in diabetes mellitus," Diabetologia Croatica, vol. 31, no. 2, pp. 85-103, 2002.

[8] S. B. Appannanavar, K. Goyal, R. Garg, P. Ray, M. Rathi, and N. Taneja, "Shigellemia in a post renal transplant patient: a case report and literature review," Journal of Infection in Developing Countries, vol. 8, no. 2, pp. 237-239, 2014.

[9] S. M. Alavi, A. D. Khosravi, A. Sarami, A. Dashtebozorg, and E. A. Montazeri, "Bacteriologic study of diabetic foot ulcer," Pakistan Journal of Medical Sciences, vol. 23, pp. 681-684, 2007.

[10] S. H. Al-Salihi and I. A. M. Jumaah, "Bacterial infection of diabetic foot ulcer," Diyala Journal, vol. 9, pp. 15-21, 2013.

[11] L. B. Gadkowski and J. E. Stout, "Cavitary pulmonary disease," Clinical Microbiology Reviews, vol. 21, no. 2, pp. 305-333, 2008.

[12] N. A. Longdoh, J. C. N. Assob, S. D. Nsagha et al., "Uropathogens from diabetic patients with asymptomatic bacteriuria and urinary tract infections," The West London Medical Journal, vol. 5, pp. 7-14, 2013.

[13] S. Prabuseenivasan, M. Jayakumar, and S. Ignacimuthu, "In vitro antibacterial activity of some plant essential oils," BMC Complementary and Alternative Medicine, vol. 6, article 39, 2006.

[14] A. I. M. Hoepelman, R. Meiland, and S. E. Geerlings, "Pathogenesis and management of bacterial urinary tract infections in adult patients with diabetes mellitus," International Journal of Antimicrobial Agents, vol. 22, no. 2, pp. S35-S43, 2003.

[15] M. Mittal, M. R. Siddiqui, K. Tran, S. P. Reddy, and A. B. Malik, "Reactive oxygen species in inflammation and tissue injury," Antioxidants and Redox Signaling, vol. 20, no. 7, pp. 1126-1167, 2014.

[16] B. Poljsak, D. Šuput, and I. Milisav, "Achieving the balance between ROS and antioxidants: when to use the synthetic antioxidants," Oxidative Medicine and Cellular Longevity, vol. 2013, Article ID 956792, 11 pages, 2013.

[17] S. D. Shruthi, P. S. S. Ganapathy, R. S. Padmalatha, and Y. L. Ramachandra, "In vitro, in vivo and in silico antiarthritic studies of polyprenol from Kirganelia reticulata Baill," Journal of Biochemical Technology, vol. 3, pp. S221-S226, 2012.

[18] A. S. Ravipati, L. Zhang, S. R. Koyyalamudi et al., "Antioxidant and anti-inflammatory activities of selected Chinese medicinal plants and their relation with antioxidant content," BMC Complementary and Alternative Medicine, vol. 12, article 173, 2012.

[19] E. Pooley, A Field Guide to Wild Flowers of KwaZuluNatal and the Eastern Region, Natal Flora Publication Trust, Durban, South Africa, 1998.

[20] B.-E. Van Wyk, H. de Wet, and F. R. Van Heerden, "An ethnobotanical survey of medicinal plants in the southeastern Karoo, South Africa," South African Journal of Botany, vol. 74, no. 4, pp. 696-704, 2008.

[21] S. O. Oyedemi, G. Bradley, and A. J. Afolayan, "Ethnobotanical survey of medicinal plants used for the management of diabetes mellitus in the Nkonkobe municipality of South Africa," Journal of Medicinal Plants Research, vol. 3, no. 12, pp. 1040-1044, 2009.

[22] G. Bringmann, D. Menche, R. Brun, T. Msuta, and B. Abegaz, "Bulbine-knipholone, a new, axially chiral phenylanthraquinone from Bulbine abyssinica (Asphodelaceae): isolation, structural elucidation, synthesis, and antiplasmodial activity," European Journal of Organic Chemistry, vol. 6, pp. 1107-1111, 2002.
[23] H. Bouaziz-Ketata, N. Zouari, H. B. Salah, M. Rafrafi, and N. Zeghal, "Flavanoid profile and antioxidant activities of methanolic extract of Hyparrhenia hirta (L.) Stapf," Indian Journal of Experimental Biology, vol. 53, pp. 208-215, 2015.

[24] S. O. Oyedemi, G. Bradley, and A. J. Afolayan, "In vitro and in vivo antioxidant activities of aqueous extract of Strychnos henningsii Gilg," African Journal of Pharmacy and Pharmacology, vol. 4, no. 2, pp. 70-78, 2010.

[25] B. O. Mbaebie, H. O. Edeoga, and A. J. Afolayan, "Phytochemical analysis and antioxidants activities of aqueous stem bark extract of Schotia latifolia Jacq," Asian Pacific Journal of Tropical Biomedicine, vol. 2, no. 2, pp. 118-124, 2012.

[26] B. E. Omoruyi, G. Bradley, and A. J. Afolayan, "Antioxidant and phytochemical properties of Carpobrotus edulis (L.) bolus leaf used for the management of common infections in HIV/AIDS patients in Eastern Cape Province," BMC Complementary and Alternative Medicine, vol. 12, article 215, 2012.

[27] Mamta, S. Mehrotra, Amitabh et al., "Phytochemical and antimicrobial activities of Himalayan Cordyceps sinensis (Berk.) Sacc.", Indian Journal of Experimental Biology, vol. 53, no. 1, pp. 36-43, 2015.

[28] İ. Gülçin, H. A. Alici, and M. Cesur, "Determination of in vitro antioxidant and radical scavenging activities of propofol," Chemical and Pharmaceutical Bulletin, vol. 53, no. 3, pp. 281285, 2005.

[29] M. M. Majumder, E. H. Mazumder, M. A. Alam, R. Akter, M. Rahman, and S. D. Sarker, "Antioxidant and membrane stabilizing properties of Ichnocarpus frutescens," Journal of Natural Remedies, vol. 8, no. 2, pp. 209-215, 2008.

[30] W. M. Otang, D. S. Grierson, and R. N. Ndip, "Antifungal activity of Arctotis arctotoides (L.f.) O. Hoffm. and Gasteria bicolor Haw. against opportunistic fungi associated with human immunodeficiency virus/acquired immunodeficiency syndrome," Pharmacognosy Magazine, vol. 8, no. 30, pp. 129134, 2012.

[31] R. J. Williams, J. P. E. Spencer, and C. Rice-Evans, "Flavonoids: antioxidants or signalling molecules?" Free Radical Biology and Medicine, vol. 36, no. 7, pp. 838-849, 2004.

[32] S. K. Sharma and A. P. Singh, "In vitro antioxidant and free radical scavenging activity of Nardostachys jatamansi DC," Journal of Acupuncture and Meridian Studies, vol. 5, no. 3, pp. 112-118, 2012.

[33] C. Gonçalves, T. Dinis, and M. T. Batista, "Antioxidant properties of proanthocyanidins of Uncaria tomentosa bark decoction: a mechanism for anti-inflammatory activity," Phytochemistry, vol. 66, no. 1, pp. 89-98, 2005.

[34] G. W. Plumb, K. R. Price, and G. Williamson, "Antioxidant properties of flavonol glycosides from green beans," Redox Report, vol. 4, no. 3, pp. 123-127, 1999.

[35] Y. Chen, Y. Miao, L. Huang et al., "Antioxidant activities of saponins extracted from Radix Trichosanthis: an in vivo and in vitro evaluation," BMC Complementary and Alternative Medicine, vol. 14, article 86, 2014.

[36] A. L. Souto, J. F. Tavares, M. S. da Silva, M. F. F. M. de Diniz, P. F. de Athayde-Filho, and J. M. B. Filho, "Anti-inflammatory activity of alkaloids: an update from 2000 to 2010," Molecules, vol. 16, no. 10, pp. 8515-8534, 2011.

[37] J. Chao, T.-C. Lu, J.-W. Liao et al., "Analgesic and anti-inflammatory activities of ethanol root extract of Mahonia oiwakensis in mice," Journal of Ethnopharmacology, vol. 125, no. 2, pp. 297303, 2009. 
[38] A. Mahboubi, M. Kamalinejad, A. M. Ayatollahi, and M. Babaeian, "Total phenolic content and antibacterial activity of five plants of Labiatae against four foodborne and some other bacteria," Iranian Journal of Pharmaceutical Research, vol. 13, no. 2, pp. 559-566, 2014.

[39] E. T. dos Santos, M. L. A. Pereira, C. F. P. G. da Silva et al., "Antibacterial activity of the alkaloid-enriched extract from Prosopis juliflora pods and its influence on in vitro ruminal digestion," International Journal of Molecular Sciences, vol. 14, no. 4, pp. 8496-8516, 2013.

[40] R. Mayer, G. Stecher, R. Wuerzner et al., "Proanthocyanidins: target compounds as antibacterial agents," Journal of Agricultural and Food Chemistry, vol. 56, no. 16, pp. 6959-6966, 2008.

[41] P. Avato, R. Bucci, A. Tava et al., "Antimicrobial activity of saponins from Medicago sp.: structure-activity relationship," Phytotherapy Research, vol. 20, no. 6, pp. 454-457, 2006.

[42] B. R. Min, W. E. Pinchak, R. Merkel, S. Walker, G. Tomita, and R. C. Anderson, "Comparative antimicrobial activity of tannin extracts from perennial plants on mastitis pathogens," Scientific Research and Essays, vol. 3, no. 2, pp. 66-73, 2008.

[43] V. Srinivasahan and B. Durairaj, "Antioxidant and free radical scavenging effect of Morinda citrifolia fruit extract," International Journal of Pharmacy and Pharmaceutical Sciences, vol. 6, no. 4, pp. 55-59, 2014 


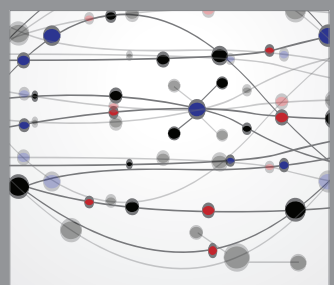

The Scientific World Journal
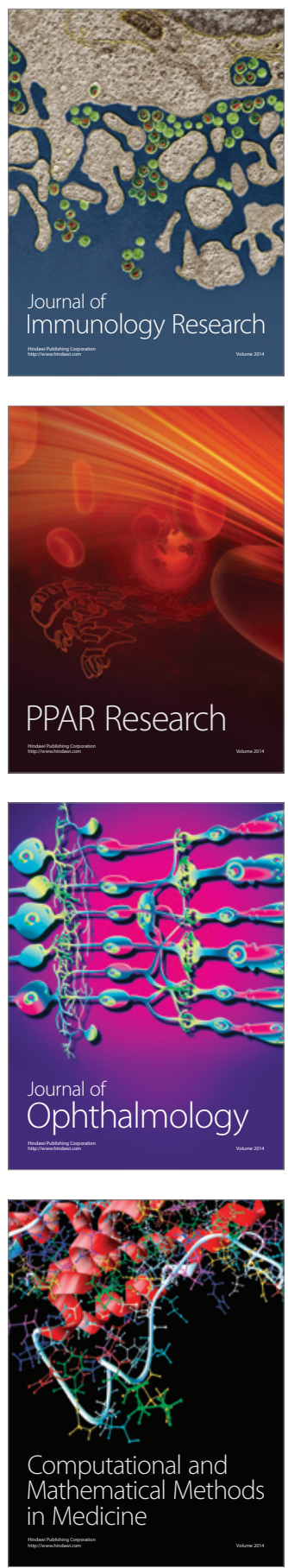

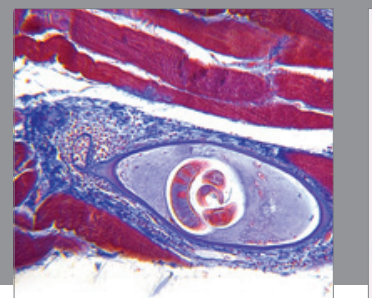

Gastroenterology

Research and Practice
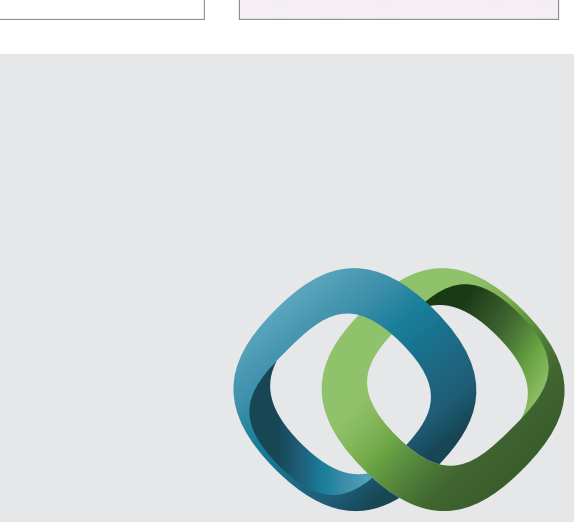

\section{Hindawi}

Submit your manuscripts at

http://www.hindawi.com
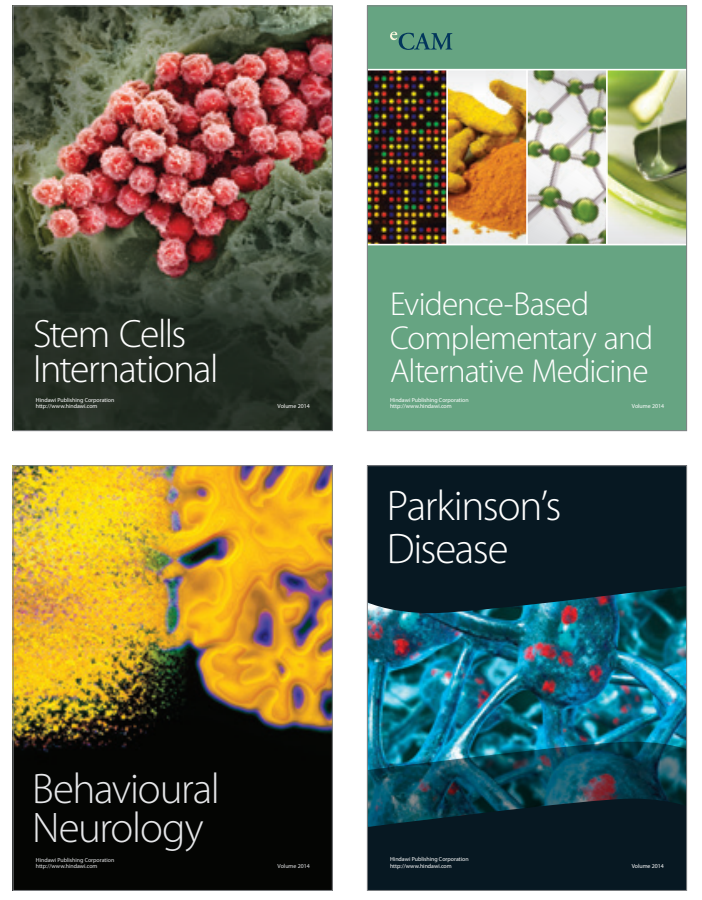
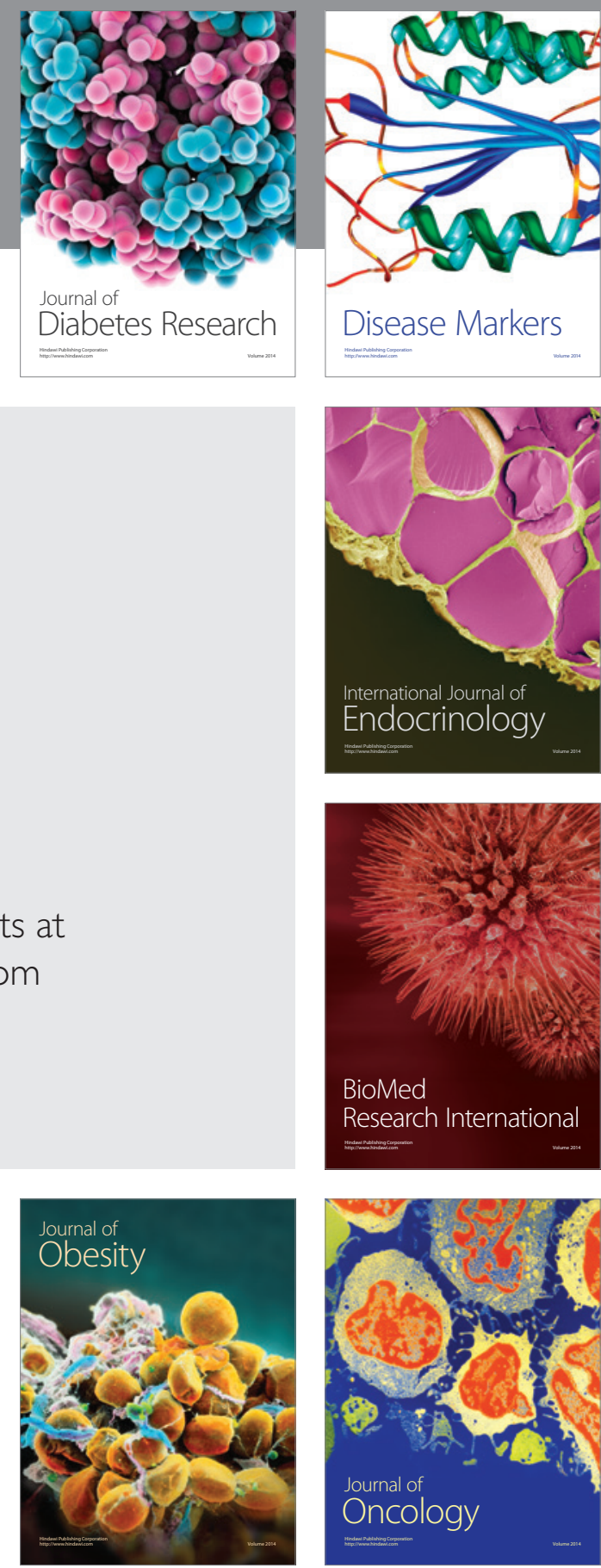

Disease Markers
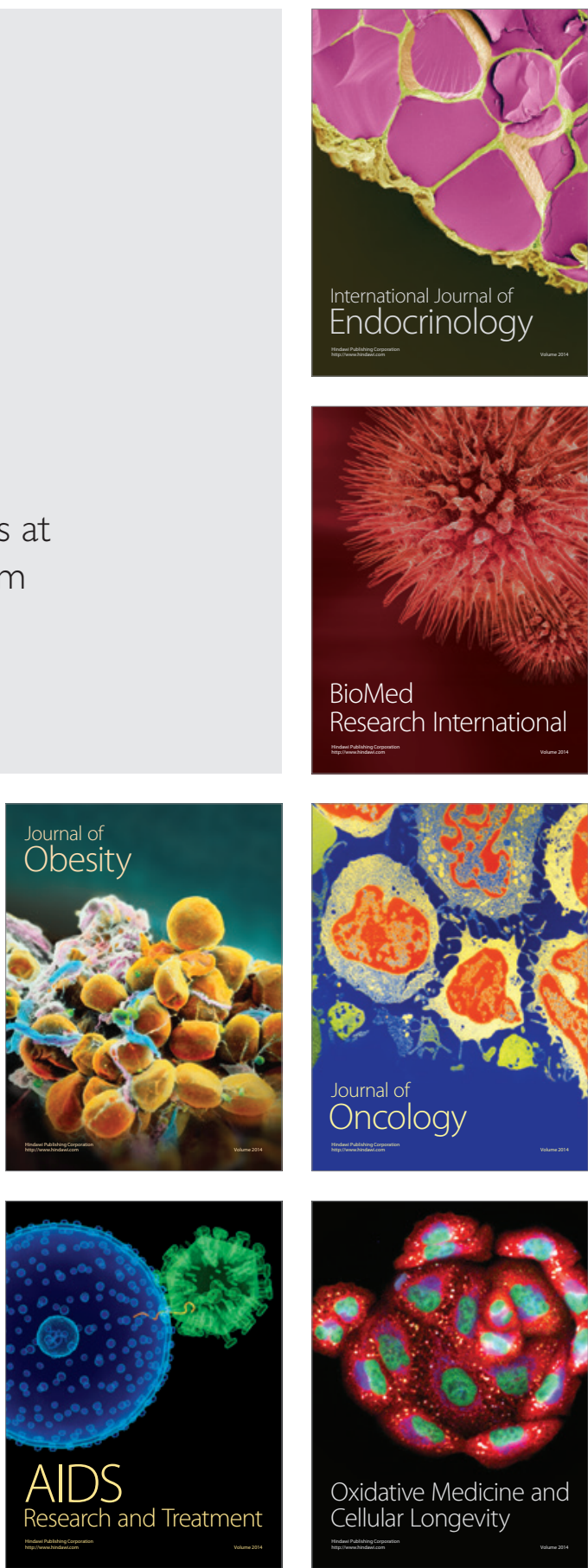